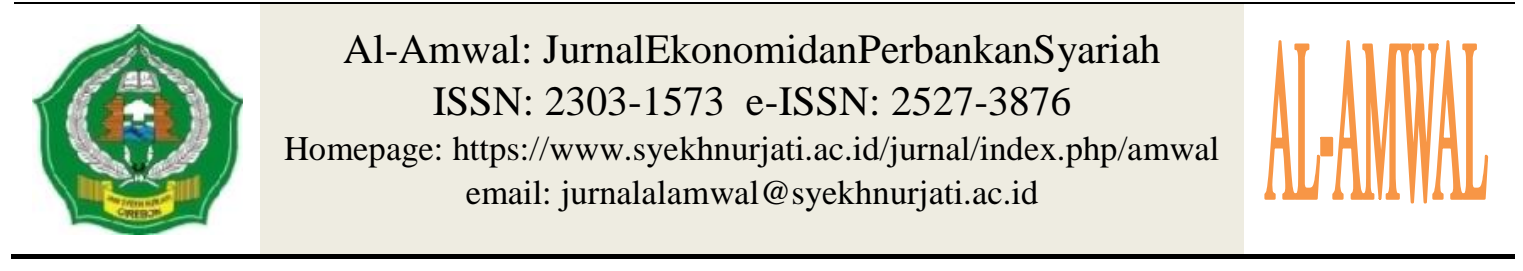

\title{
INFRASTRUCTURE INFLUENCE, SCHOOL CONDITIONS AND THE ECONOMIC TOWARDS SCHOOL DISPUTES IN CIREBON DISTRICT
}

\author{
Syaeful Bakhri, \\ Faculty of Sharia and Islamic Economics of IAIN SyekhNurjati of Cirebon \\ Email: sultan01aulia@yahoo.com \\ Ahmad Amin Mubarok \\ Faculty of Education and Teaching Training of IAIN SyekhNurjati of Cirebon \\ Email: ahmadaminmubarok@ syekhnurjati.ac.id
}

\begin{abstract}
One of the determinants of the Human Development Index (HDI) is the education sector. The condition of education in Indonesia, including in coastal areas such as Cirebon Regency, still finds problems related to the dropout rate. As with the Ministry of Education and Culture data, the Rough Participation Rate from SD to Higher Education in Cirebon Regency is still at number 21 out of 27 cities/regencies in West Java. The purpose of this study was to determine what factors can reduce the dropout rate. This research is a qualitative descriptive study. Resource persons in this study were 22 respondents familiar with the conditions of education in the Cirebon Regency, including elements of the Regional Research and Development Planning Agency, the Education Office, Educators, education, and community leaders who were concerned about education problems. The method used is the Process Hierarchy Analysis $(A H P)$. With this analysis, the researcher tries to arrange policy priorities based on each factor's weight so that a priority scale is obtained to reduce the dropout rate in Cirebon Regency. The results showed that the priority order based on the hierarchy is that the infrastructure factor is the priority with a weight of $24.89 \%$. There are aspects of school conditions $22.38 \%$ and economic conditions $19.92 \%$.
\end{abstract}

Keywords: Infrastructure, Schools, Economics, and Dropouts.

\begin{abstract}
Abstrak
Salah satu factor penentu Indeks Pembangunan Manusia (IPM) adalah sector pendidikan. Kondisi pendidikan di Indonesia termasuk di daerah pesisir seperti di Kabupaten Cirebon masih ditemukan adanya permasalahan salahsatunya adalah terkait angka putus sekolah. Sebagaimana data Kemedikbud, Angka Partispasi Kasardari SD hingga PerguruanTinggiKabupaten Cirebon
\end{abstract}


masih berada di urutan ke 21 dari 27 Kota/Kabupaten yang ada di Jawa Barat. Tujuan penelitian ini adalah untuk mengetahui faktor-faktor apa saja yang mampu menurunkan Angka Putus Sekolah. Penelitian ini merupakan penelitian deskriptif kualitatif. Narasumber pada penelitian ini sebanyak 22 responden yang paham dengan kondisi Pendidikan di Kabupaten Cirebon, meliputi unsure Badan Perencanaan Pembangunan Penelitian dan Pengembangan Daerah, Dinas Pendidikan, Tenaga Pendidik, kependidikan dan dari tokoh masyarakat yang concern dalam masalah pendidikan. Metode yang digunakan adalah Analisis Hirarkhi Proses (AHP), dengan analisis ini peneliti mencoba menyusun prioritas kebijakan berdasarkan bobot pada masingmasing factor sehingga didapatkan skala prioritas untuk menurunkan angka putus sekolah di Kabupaten Cirebon. Hasil penelitian di dapatkan urutan prioritas berdasarkan hirarkhi adalah factor infrastruktur menjadi prioritas pertama dengan bobot $24,89 \%$, kemudian ada aspek Kondisi Sekolah 22,38 \% dan kondisi ekonomi 19,92\%.

Kata kunci: Infrastruktur, Sekolah, EkonomidanPutusSekolah.

\section{INTRODUCTION}

One of the determinants of the Human Development Index (HDI) is the education sector. Education in which humans can grow and develop both physically, mind and spirit (Sajjad, Iqbal, Siddiqui, \& Siddiqui, 2012), as well as demands for reform and globalization competition to improve the quality of life and continue the country's economic development (Okumu, Nakajjo, \&Isoke, 2008). It is said so because education is a basis in shaping human quality. Education can produce knowledgeable and broad-minded individuals so that they are highly competitive, including improving the workforce's quality as the primary driver of development (Khairunnisa, Hartoyo, \&Anggraeni, 2014).

Considering the vital role of education in the success of a country's development must be made to improve the quality of education, starting with opening the broadest possible opportunity for the population to receive education and improve the quality and quantity of education facilities and infrastructure. To find out how many people use educational facilities can be seen from the percentage of the population according to school participation; school participation in a common area is known by several indicators to find out, one of which is the School Participation Rate (APS).

In the Ministry of Education and Culture's data, regarding the Gross Participation Rate (APK) of Regencies / Cities in West Java 2018/2019, it can be seen that the APK condition in Cirebon Regency is at $75 \%$ and is below the Regencies / Cities of West Java. If based on the order of the Regency / City with the highest to lowest GER, the APK for Cirebon Regency is in the 21st position out of 27 Regencies / Cities in West Java, including some of the closest areas in Cirebon Regency, namely Kuningan Regency, Majalengka Regency and Regency Indramayu. This, of course, illustrates the quality of education in Cirebon Regency, especially concerning the level of school participation and dropout rates in the Cirebon Regency.

Dropouts can be defined as those who have attended one level of education, but they were not enrolled at one formal education (Riyadiningsih\&Astuti, 2013). This coincides with the opinion (Abraham, 2011) which states that children who drop out of school are children who do not have access to education because they stop studying either in the middle of the school year or the end of the school year for various reasons that require or force them to quit school. (Benjamin, Pati, \&Singkoh, 2017). 
According to the Center for Child \& Family Policy (Blue, 2011), there are one or more factors in each student who are at risk of causing children to drop out of school. In this case, it can be seen that many factors are thought to contribute to the increase in dropout rates, as (Shahidul\& Karim, 2015) states that the dropout rate does not occur due to one factor, but the result of the composition of several factors. There is a lot of previous literature that has discussed some of these matters. In (P.-R. Agénor, 2008), it is explained that infrastructure services are one of the causes; infrastructure can affect labor production in education services, including schools' quality or condition. (Branham, 2004) added that several efforts to increase attendance and reduce dropout rates provide adequate school buildings and improve these school buildings' quality. (Zainuri, Matsum, \& Thomas, 2014) confirms that the most dominant factor causing school dropouts is parents' income. Parents of children dropping out of school also because of low and irregular incomes. So that the income earned is only enough to help meet the needs of daily life.

Some argue that economic conditions are an aspect that affects the dropout rate (Shahidul\& Karim, 2015) which states "The financial factors constrain parents more especially those who have lower socioeconomic status compared to those who have higher status. Parents with lower socio-economic status face difficulties to bear the expenses of their daughters' education". (Bahri, 2017) also confirmed that the main cause of dropping out of school was due to the economic factors of poor families. However, this is contrary to the empirical findings (Fatimah, 2015) which explains that the socio-economic conditions of parents are not a factor in dropping out of school.

Improving the quality of human resources must be continuously improved in quality and quantity (Darmawan, 2017). By not only pursuing welfare index numbers, the average level of community education for the nation's readiness to face global challenges (Basrowi\&Juariyah, 2010), but what is not much more important is education that must be able to prepare a quality generation for the development of children's education their child. In connection with the various phenomena in the previous research that the author has described above, the author feels interested in analyzing what factors cause the dropout rate in Cirebon Regency.

\section{LITERATURE REVIEW \\ Overview of Cirebon Regency}

Cirebon Regency is part of West Java Province, located in the eastern region and is the boundary and the gateway to Central Java Province. Based on its geographical location, Cirebon Regency is in the position of 108040 '- 108048' East Longitude and 6o30'- 7o00' South Latitude, which is bounded by Indramayu Regency in the north, Majalengka Regency in the northwest, Kuningan Regency in the south and Brebes Regency in the east. Based on demographic conditions, Cirebon Regency is one of the regencies in West Java Province, which has a large enough population. Cirebon regency administrative area is $990.36 \mathrm{~km} 2$, and the population in 2017 as many as 2.159 .577 people. The population of 1 battery bigger men than women, as many as 1.106.997 people, while the women totaled 1.052 .580 million inhabitants with the sex ratio is 105,17 . 


\section{Dropout Rate}

According to Gunawan (Fatimah, 2015), dropping out of school is a term used for former students who cannot complete a level of education, so they cannot continue their studies to the next level of education. According to the limited time children have in low-income families, the cause of children dropping out of school requires them to be involved in productive activities and long household activities, both in domestic household activities and work in the public sector to generate income. This understanding is in line with the opinion (Ahmad, 2011) which states that what is meant by dropping out of school is the cessation of learning of a student whether it occurs at the beginning, middle, or end of the school year which is due to specific reasons that require the person to quit school.

\section{Accessibility}

Accessibility in question is the accessibility of education, which is the convenience given to every community member to use their opportunity to enter an educational program. Access can be in the form of non-discriminatory social attitudes, political policies aimed at common interests, in-laws, and regulations that support and prevent discrimination, the availability of a physical, educational environment easily accessible or accessible. The availability of suitable teaching and learning aids and affordable education costs and allowing every member of the community to use the opportunity to take part in the learning/teaching process in the education program chosen by Satria (Perdana, 2015). Accessibility here can include many things, as according to Carneiro in (Perdana, 2015) dividing two accessibility treatments, namely:

1. Financial accessibility is defined as "the ability of individuals," such as paying tuition fees (financial accessibility, defined as the individual ability to pay for education).

2. Anything related to physical accessibility. Then Carneiro termed it in his definition as transportation, time, and money seeking to obtain educational opportunities.

\section{Economic Conditions}

In this case, economic conditions are influenced by many factors, such as the poor condition of the elderly, which is caused by poverty and underdevelopment. According to economic conditions, it can become an obstacle for a person to fulfill his wishes, including continuing or completing his education. Limited assets, savings to be proud of, lack of unique skills and limited abilities, and other factors (Sugianto, 2017). Several indicators of economic conditions here include:

1. Parents' net income

2. Number of dependent family expenses

3. The state of the house or place of residence

The lower the family's economic condition, the more likely it is that children in a family experience the possibility of dropping out of school. Likewise, vice versa, if the level of the economic condition of a family is getting smaller, the less likely it is that a child in a family will drop out of school (Aristin, 2015). This is because children with low economic backgrounds tend to get less guidance and direction from their parents. After all, parents tend to be more concerned about meeting their daily needs (Darmawan, 2017). 


\section{METHOD}

The approach used in this study is to use the AHP (Process Hierarchy Analysis) method. This method can solve both qualitative and quantitative problems. AHP according to Thomas L. Saaty in (Nurdiyanto\&Meilia, 2016) is a decision support model that will help describe multifactor or multi-complex problems into a hierarchy. This analysis is considered important because it can map the implementation of policies that need to be taken (Fauzi et al., 2019) through weighting policy criteria (Mauko et al., 2018). In the process, AHP includes the values of personal considerations logically which are based on experience, knowledge, and the results of imagination. AHP is also in the process of providing a framework for group participation in decision-making as an effort to solve problems (Meilani, 2013). The use of the AHP method in this study is intended to find out in more detail what policies need to be prioritized in overcoming the dropout rate while increasing the School Participation Rate in Cirebon Regency.

To get a clearer and more accurate picture of priority policies, researchers involved several elements from various agencies who were considered to have sufficient knowledge related to education development in Cirebon Regency as resource persons. Through the consideration of representation, 20 (twenty) resource persons in this study came from stakeholders directly related to educational activities, namely teachers, students, Bappelitbangda, the Education Council, and the education officials who were given the authority to become education regulators. Meanwhile, secondary data in the form of data obtained from BPS, the Education Office, and school data are used to enrich research.

\section{RESULT AND DISCUSSION}

\section{Result}

The results of the field findings are as described in the table and figure as follows:

Table 1. Result of Process Hierarchy Analysis

\begin{tabular}{lrlrr}
\hline \multirow{2}{*}{ First Level } & $\begin{array}{r}\text { Weight Of } \\
\text { First Level }\end{array}$ & \multicolumn{1}{c}{ Second Level } & Weight & $\begin{array}{c}\text { Priority of } \\
\text { Second Level }\end{array}$ \\
\hline Regulation & 13.18 & Institutional & 30.01 & 3.95 \\
& & Equal Opportunity & 40.52 & 5.34 \\
& & Expansion of Access & 29.47 & 3.88 \\
HR conditions & \multirow{2}{*}{19.63} & Teacher Quality & 47.23 & 9.27 \\
& & Quantity Master & 30.72 & 6.03 \\
& & The number of students & 22.05 & 4.33 \\
Economic Conditions & \multirow{2}{*}{19.92} & Guardian's Financial Condition & 50.00 & 9.96 \\
School Conditions & & Local Community Economy & 50.00 & 9.96 \\
& \multirow{2}{*}{22.38} & Governance & 18.70 & 4.18 \\
& & Accountability & 26.17 & 5.86 \\
& & Quality & 40.40 & 9.04 \\
Access \& & & Public Imaging & 14.73 & 3.30 \\
Infrastructure & \multirow{2}{*}{24.89} & Road Availability & 43.68 & 10.87 \\
& & Availability of Transportation & 56.32 & 14.02 \\
& & & & 100.00 \\
\hline
\end{tabular}

Source: Primary data, processed (2018) 


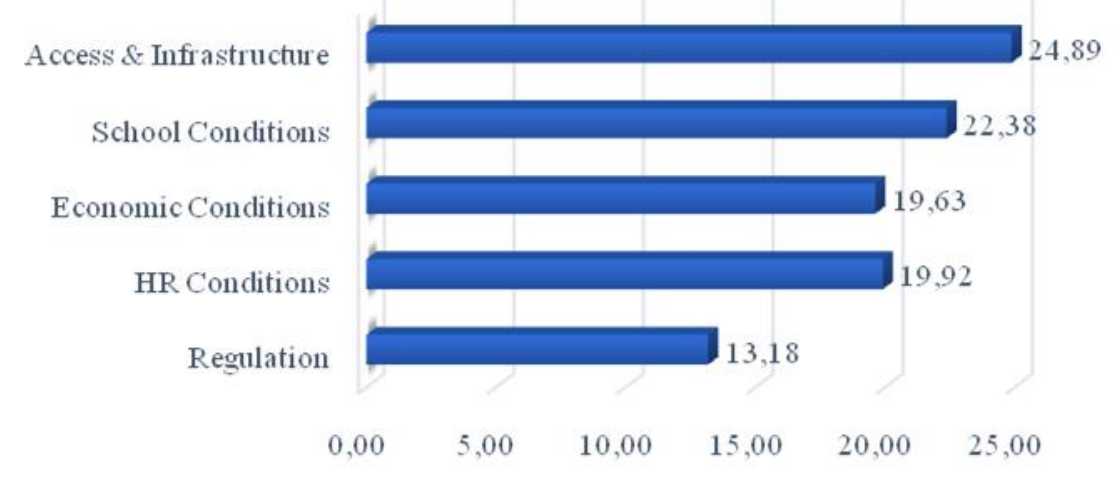

Figure 1.Figures Decline End School in Cirebon Regency

From the AHP analysis results, it was found that the access and infrastructure factors had the highest percentage at 24.89 percent. The second priority after access and physical infrastructure are school conditions, with a ratio of 22.38 percent. The condition of human resources is also essential to support the decline in dropout rates in Cirebon Regency. This can be seen in the table above, ranked third with a percentage reaching 19.92 percent. The last two factors, namely economic conditions with a 19.63 percent rate and regulations with a 13.18 percent ratio, are in the fourth and fifth priorities.In more detail, each of these factors is explained through several forming variables, which will be defined as follows:

\section{Access and Physical Infrastructure}

Table 2.Physical Infrastructure

\begin{tabular}{lr}
\hline Physical Infrastructure & Percentage Level \\
\hline Road Availability & 43.68 \\
Availability of Transportation & 56.32 \\
& 100 \\
\hline Source: Primary data, processed (2018)
\end{tabular}

Source: Primary data, processed (2018)

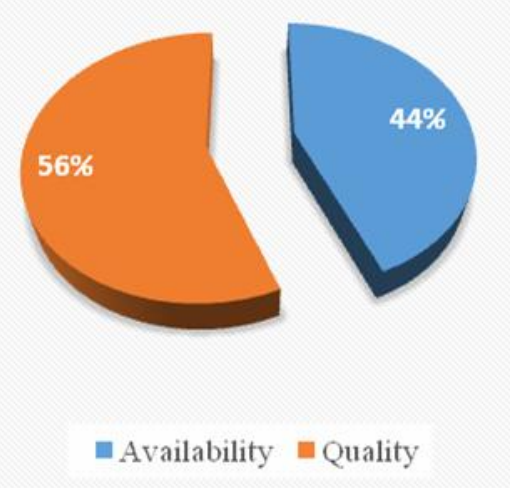

Figure 2.Physical Infrastructure 
Access and physical infrastructure are the priority factors that concern respondents to improve education in Cirebon Regency. The availability of roads and transportation availability are both important factors in supporting the reduction in dropout rates in Cirebon Regency. As shown in Figure 2 above, the respondents think that road availability has a weight of $43.68 \%$ and that transportation availability has a value of $56.32 \%$.

\section{School Conditions}

Table 3.School Conditions

\begin{tabular}{lrr}
\hline \multicolumn{1}{c}{ School Conditions } & Level Weights & Percentage Level \\
\hline Governance & $1 / 5$ & 18.70 \\
Accountability & $1 / 4$ & 26.17 \\
Quality & $2 / 5$ & 40.40 \\
Public Imaging & $1 / 7$ & 14.73 \\
& & 100.00 \\
\hline
\end{tabular}

Source: Primary data, processed (2018)

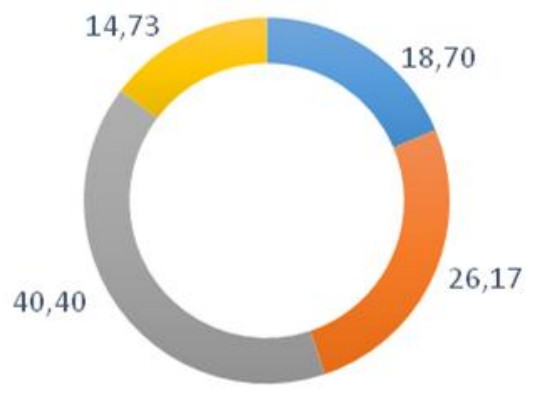

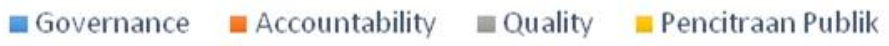

Figure 3.School Conditions

The second rank is the condition of the school, which has a weighted value of 22.38 percent. The school quality variable is considered the most crucial variable to be prioritized to reduce the dropout rate in Cirebon Regency. Based on the results of the analysis, it is known that the quality variable is at the highest level, with a percentage reaching 40.40 percent, followed by accountability reaching $26.17 \%$.

\section{HR conditions}

Table 4.HR conditions

\begin{tabular}{lrr}
\multicolumn{1}{c}{ HR conditions } & \multicolumn{1}{c}{$\begin{array}{c}\text { First Level } \\
\text { Weights }\end{array}$} & First Level Percentage \\
\hline Teacher Quality & $2 / 9$ & 22.05 \\
Quantity Master & $1 / 3$ & 30.72 \\
The number of students & $1 / 2$ & 47.23 \\
& & 100.00 \\
\hline
\end{tabular}

Source: Primary data, processed. (2018) 


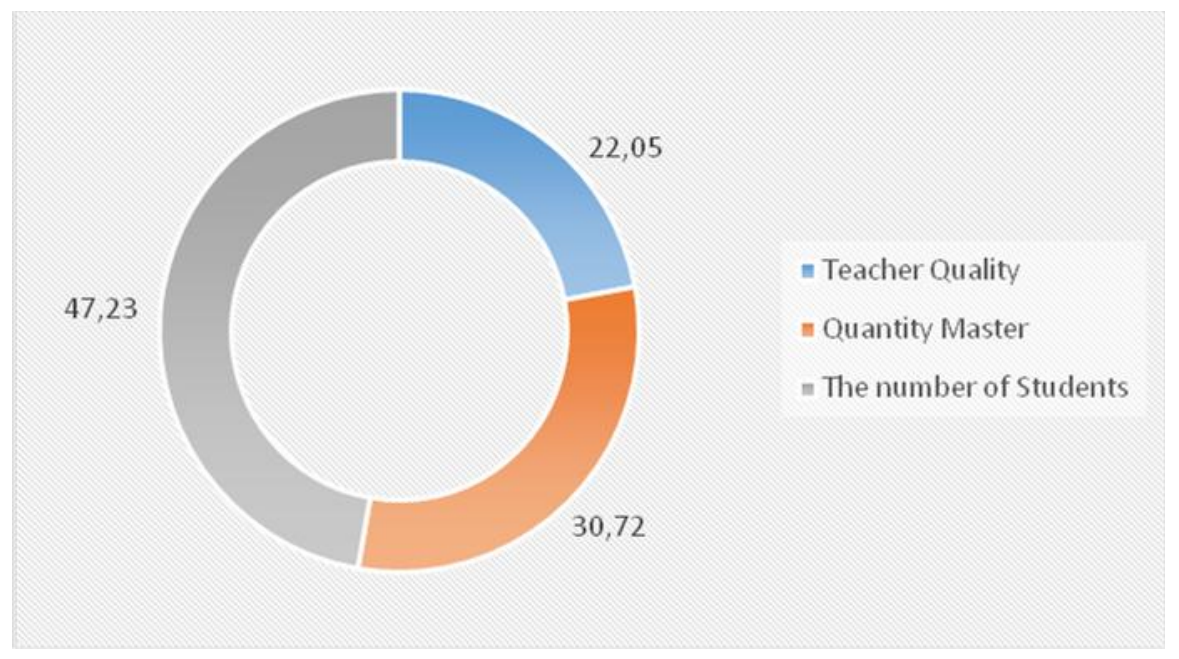

Figure 4.HR conditions

The third rank is the condition of human resources, which has a value weight of 19.92 percent. Human Resources are very important for the creation of quality education. Human Resources in education include principals, educators (teachers), employees, and school committees.

Based on the results of the analysis, it is known that the variable number of students is at the highest level, with a percentage reaching 47.23 percent, followed by the number of teachers and the quality of teachers with a percentage of 30.72 percent and 22.05 percent respectively.

\section{Economic Conditions}

Table 5.Economic Conditions

\begin{tabular}{|c|c|c|}
\hline Economic Conditions & $\begin{array}{l}\text { First Level } \\
\text { Weights }\end{array}$ & $\begin{array}{l}\text { First Level } \\
\text { Percentage }\end{array}$ \\
\hline Guardian's Financial Condition & $1 / 2$ & 50,00 \\
\hline Local Community Economy & $1 / 2$ & $\begin{array}{r}50,00 \\
100.00 \\
\end{array}$ \\
\hline
\end{tabular}

Source: Primary data, processed. (2018)

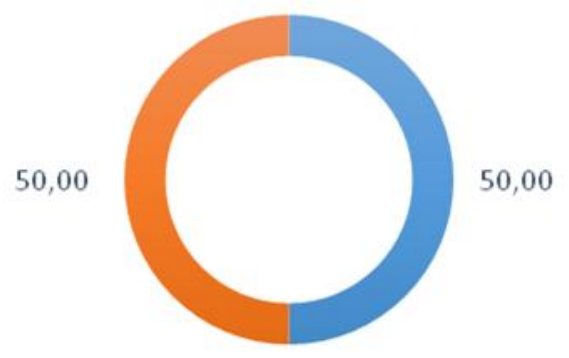

- The financial condition of

- The economy of

The student's guardian

The surrounding community

Figure 5.Economic Conditions 
Economic conditions are the fourth priority factor, with a value weight of 19.63 percent. This economic condition consists of the student guardian's financial condition and the economy of the surrounding community.

The variables of the guardian of students' financial condition and the economy of the surrounding community have a weighted value of 50.00 percent. With these findings condition of financial economics and economic guardian surrounding communities are equally important in terms of a decrease in the numbers dropping out of school in Cirebon.

\section{Regulation}

Table 6.Regulation

\begin{tabular}{lr}
\hline \multicolumn{1}{c}{ Regulation } & First Level Percentage \\
\hline Institutional & 30.01 \\
Equal Opportunity & 40.52 \\
Expansion of Access & 29.47 \\
& 100.00 \\
\hline
\end{tabular}

Source: Primary data, processed. (2018)

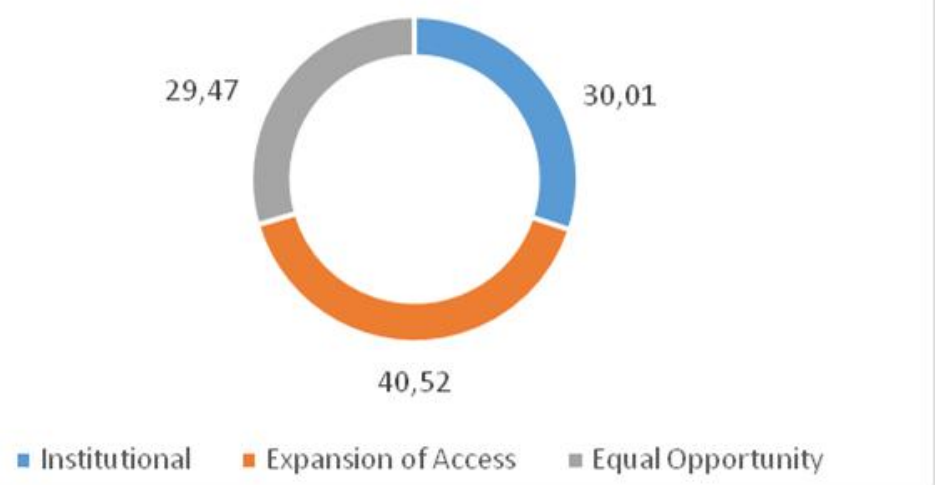

Figure 6.Regulation

Based on the regulatory analysis results above, the highest percentage was equal opportunity equal to $40.52 \%$, followed by institutions at $30.01 \%$, and the lowest was the expansion of access by $29.47 \%$. The various existing regulations relating to the urgency of education, even to technical matters, have been clearly stated in the law. But at the stage of implementation, various obstacles are facing it. These constraints have to be found out so that access to equal education can be achieved.

Equity and expansion of education is a public policy implemented by the government, both the Central Government and the Regional Government. In executing a general guideline, it must be carried out with careful planning.

Table 7. Priority Ranking Based on Process Hierarchy Analysis (AHP)

\begin{tabular}{lcc}
\hline \multicolumn{1}{c}{ Second Level } & \multicolumn{2}{c}{ Priority of } \\
& Second Level & Priority \\
\hline Availability of Transportation & 14.02 & P1 \\
Availability of good roads & 10.87 & P2
\end{tabular}




\begin{tabular}{lrc}
\hline \multicolumn{1}{c}{ Second Level } & \multicolumn{2}{c}{ Priority of } \\
& Second Level & Priority \\
\hline Guardian's Financial Condition & 9.96 & P3 \\
Local Community Economy & 9.96 & P4 \\
Quantity Master & 9.27 & P5 \\
Quality & 9.04 & P6 \\
Accountability & 6.03 & P7 \\
Equal Opportunity & 5.34 & P8 \\
Teacher Quality & 5.34 & P9 \\
The number of students & 4.33 & P10 \\
Governance & 4.18 & P11 \\
Institutional & 3.96 & P12 \\
Expansion of Access & 3.88 & P13 \\
Public Imaging & 3.30 & P14 \\
& 100.00 & \\
\hline
\end{tabular}

Source: Primary data, processed (2018)

The table above shows the priority of policy making starting from P1, P2, P3 and so on.

\section{Discussion}

As we all know, to handle the dropout rate, policies are needed that can prevent and handle cases of school dropouts. Several procedures can be developed for this effort. Based on the AHP data processing results above, in the calculation of the first level priority ranking contained in table 1 . The factors that have a high value in reducing the dropout rate in Cirebon Regency are the infrastructure factor with a weighting value of $24.89 \%$, and the school condition factor with a weighted cost of $22,38 \%$. As for the second level priority ranking order in table 2., it is found in transportation availability, parts of the availability of right roads, and characteristics of the economic condition of the guardians of students.

Many factors influence the dropout rate. As (Shahidul\& Karim, 2015) states, the dropout rate does not occur only because of one factor, but the result of the composition of several factors. Access factors and infrastructure and school conditions that show the highest priority scores are appropriate and strengthen the results of empirical studies (Branham, 2004), which previously proved that school infrastructure's quality had a significant effect on birth dropout rates. It also explains that students tend not to go to school when the school infrastructure is less supportive, such as buildings that need repair or lack of cleaning service staff. The importance of infrastructure in the success of increasing the quantity of education is also discussed (PR Agénor\&Canuto, 2014) and reveals that infrastructure is what determines the outcome of efforts to improve education because, with the supporting infrastructure, students will be encouraged to go to school (Alexander, 2008 ). Based on this, infrastructure access is something that certainly needs to be prepared optimally. From the results of this analysis, respondents were able to judge that access and infrastructure were essential to be the main priorities for reducing the dropout rate in Cirebon Regency.

The school condition factor that received the second-highest score after the access and infrastructure factor resulted from data processing in table 1. The above is by several previous studies that have successfully explored several effects of dropout rates, including school conditions. In (Abraham, 2011) it is explained that the provision of systematic rights, both the 
quantity and quality of infrastructure, needs to be carried out correctly. Poor student performance and poor graduate performance can be caused by schools' inability to measure changes in student learning needs. The management of damaged infrastructure, school buildings, tables, chairs, libraries, and other infrastructure needs to be repaired proactively.

Meanwhile, in table 2. It is known that the three policy priorities with the highest scores are compared to the other eleven aspects. The first and second aspects are part of access and infrastructure conditions, which are the main policies in reducing the dropout rate in the Cirebon Regency. These two aspects are aspects of the availability of transportation and elements of the right roads' availability. This finding is in line with the results of Shadreck in (Shadreck, 2013), which explains that accessibility to school contributes to the decline in dropouts. Inadequate transportation facilities can be a significant cause of dropping out of school. Hussain's research (Hussain, Salfi, \& Khan, 2011) also states that the lack of adequate physical facilities at schools can impact the high dropout rate. This shows the importance of access and support for infrastructure to support educational activities in the Cirebon Regency area. Infrastructure access is, of course, something that needs to be prepared optimally, considering that access and infrastructure are essential things to become a top priority to reduce dropout rates in Cirebon Regency.

The third highest aspect that needs to be prioritized in making policies related to decreasing school enrollment rates is the aspect of student guardians' economic condition. This supports the results of the study (Zainuri, Matsum, \& Thomas, 2014) which shows that parents' income is the most dominant factor causing children to drop out of school. This poverty condition has sedated school-age children with "low" wages. Still, some children get carried away and gradually forget their obligations to go to school (Malik \&Sumarno, 2016a) coupled with parenting factor that tends to get less. Attention and thought patterns of parents who often do not care about fulfilling their responsibilities in providing and fulfilling educational facilities for children (Malik \&Sumarno, 2016b). The study results show that the tendency of negligent parents is one of the causes of high school dropouts (Njagi\&Mwania, 2017).

Among the several priority policies, some things are no less important to put forward, namely the implementation of child protection programs, economic empowerment of families, the poor as a whole, programs to restrict early marriage (Suryanto, 2012). This is of course the work of all stakeholders, be it the local government of Cirebon Regency, the community, entrepreneurs and a number of other elements, considering that education is a fundamental element in the human development process that must be fulfilled by the cooperation between parents, society and government (Mua, Manginsela, \&Baroleh, 2017).

\section{CONCLUSION}

Based on the results of the research and discussion, the conclusions drawn in this study are as follows: The results of the analysis using AHP show that the order of priority in reducing dropout rates in the Cirebon Regency. At the first level is Conditions of access and infrastructure as the priority, with $24.89 \%$ weight. The conveniences expected dian there are aspects of School Conditions $2238 \%$ and economic conditions of $19.92 \%$. The ranking of policy priorities at the second level that can be done by local governments is P1 prioritizes the availability of transportation with a value of $14.02 \%$. P2 puts forward the availability of good roads with a weighting value of $10.87 \%$. P3 puts forward the financial conditions of guardians and the surrounding community's economic needs with a value weight of $9.96 \%$. 


\section{REFERENCES}

Abraham, NM (2011). School DroupotAmong Nigerian Children: Some Proactive Strategies Aand Solutions. African Journal of Education and Technology, 1 (3), 118-124.

Agénor, P.-R. (2008). Fiscal policy and endogenous growth with public infrastructure. Oxford Economic Papers, 60 (1), 57-87.

Agénor, PR, \&Canuto, O. (2014). Access to infrastructure and women's time allocation: Evidence and a framework for policy analysis. Revue d'Economie Du Developpement, 28 (1), 37-73. https://doi.org/10.3917/edd.281.0037

Ahmad, NS (2011). Education and Society. Yogyakarta: Word of Media.

Alexander, R. (2008). Education for All, the Quality Imperative and the Problem of Pedagogy. CREATE; Consortium for Research on Educational Access, Transitions and Equity.

Aristin, NF (2015). Factors Influencing School Dropout Children in Junior High School (SMP) in Bondowoso District. Journal of Geographic Education, 20 (1), 30-36. https://doi.org/10.1136/bmj.2.2017.513

Basrowi, \&Juariyah, S. (2010). Analysis of the Socio-Economic Conditions and Education Level of the Srigading Village Community, LabuhanMaringgai District, East Lampung Regency. Journal of Economics \& Education, 7 (1), 58-81.

Benjamin, M., Pati, A., \&Singkoh, F. (2017). The Strategy of the Education Office in Minimizing School Dropout in Bitung City. Executive Journal, 1 (1).

Blue, AL (2011). What Factors Contribute to the High School Dropout Rate? Are Students Who Live in Low-Income Economic Conditions More Likely to Drop Out? ProQuest Dissertations Publishing. https://doi.org/10.1017/CBO9781107415324.004

Branham, D. (2004). The Wise Man Builds His House Upon the Rock: The Effects of Inadequate School Building Infrastructure on Student Attendance. Social Science Quarterly. Retrieved from https://doi.org/10.1111/j.0038-4941.2004.00266.x

Darmawan, I. (2017). The Influence of Peer Socio-Economic Status and Environment on Students' Interest in Continuing Studies in Higher Education. Journal of Education and Economics, 6 (2), 156-165.

Fatimah, S. (2015). Factors that cause children to drop out of school in Mijen District, Semarang City, 2011-2014. Semarang State University.

Fauzi, P., Bakhri, S., \& Ahmad, A. A. (2019). Development of Parawista in Pangandaran Regency Post-expansion. Al-Amwal: Journal of Islamic Economics and Banking, 11 (1), 77-94. https://doi.org/10.24235/amwal.v11i1.4250

Hussain, A., Salfi, NA, \& Khan, M. (2011). Causes of Students' Dropout at Primary Level in Pakistan: An Empirical Study. International Journal of Humanities and Social Science, 1 (12), 143-151.

Khairunnisa, K., Hartoyo, S., \&Anggraeni, L. (2014). Determinants of Junior High School Participation Rates in West Java. Journal of Indonesian Economy and Development, 15 (1), 91-112. https://doi.org/10.21002/jepi.v15i1.444

Malik, HK, \&Sumarno. (2016a). Parents' Concern for Children's Education to Complete the 9 Year Compulsory Education Program. Journal of Education and Community Empowerment, 3 (4), 38-47.

Malik, HK, \&Sumarno, S. (2016b). Parents' Concern for Children's Education to Complete the 9Year Fair Program. Journal of Education and Community Empowerment, 3 (1), 38-47. https://doi.org/10.21831/jppm.v3i1.8061 
Mauko, A., B, M., \&Sugi Journalist, P. (2018). Group Decision Support System in the Selection of LQ 45 Index Shares Using the AHP, Promethee, and Borda Methods. Indonesian Applied Computer and Information Systems (JSIKTI), 1 (1), 25-34.

Meilani, S. (2013). Analysis of Labor Absorption in Magelang City with the Process Hierarchy Analysis Method (AHP). Economics Development Analysis Journal; EDAJ, 2 (4), 446-455.

Mua, VB, Manginsela, EP, \&Baroleh, J. (2017). Factors Causing Dropping Out of School Children of Farmers and Non-Farmers in Sea and Warembungan Villages, Pineleng District, Minahasa Regency. Journal of Agri-Socio-Economics, 13 (3 A), 313-322.

Nurdiyanto, H., \&Meilia, H. (2016). Decision Support System Priority Determination of Small and Medium Industry Development in Central Lampung Using Analytical Hierarchy Process (Ahp). Semnasteknomedia, 4 (1), 37-42. Retrieved from https://ojs.amikom.ac.id/index.php/semnasteknomedia/article/view/1163

Okumu, IM, Nakajjo, A., \&Isoke, D. (2008). Socio-economic Determinants of Primary School Dropout: The Logistic Model Analysis, Economic Policy Research Center, Makerere University. Economic Policy Research Center, Makekere University. Retrieved from http://mpra.ub.uni-muenchen.de/7851/ MPRA Paper No. 7851, posted 20.March 2008

Prime, NS (2015). Factors that Affect the Accessibility of Getting Education for Children in Indonesia. Journal of Education and Culture, 21 (3), 279-297. https://doi.org/10.24832/jpnk.v21i3.191

Riyadiningsih, H., \&Astuti, RP (2013). Psychological Conditions of School Dropouts. Sustainable Competitive Advantage (SCA), 3 (1).

Sajjad, H., Iqbal, M., Siddiqui, MA, \& Siddiqui, L. (2012). Socio-economic determinants of primary school dropout: Evidence from south east Delhi, India. European Journal of Social Sciences, 30 (3), 391-399.

Shadreck, M. (2013). A Study of Zhomba Cluster Secondary Schools in Gokwe District of Zimbabwe. School Based Factors and the Dropout Phenomenon, 3 (January), 51- 60. https://doi.org/10.5901/jesr.2013.v3n1p51

Shahidul, SM, \& Karim, AHMZ (2015). Factors contributing to school dropout among the girls: a review of literature. European Journal of Research and Reflection in Educational Sciences, 3 (2), 25-36.

Sugianto, E. (2017). Factors Causing High School Dropout Children in Bukit Lipai Village, BatangCenaku District, Indragiri Hulu Regency. JomFisip, 4 (2), 1-13. Retrieved from https://jom.unri.ac.id/index.php/JOMFSIP/article/view/15616..\% 0A\% 0A

Suryanto, B. (2012). Formulation of Policies and Programs to Eliminate Dropout Rates and Students Prone to Drop Out in East Java Province. In N. Akhmadi (Ed.), Research on Child Education Policy in Indonesia. Tangerang: Ministry of Education and Culture, UNICEF Indonesia, The SMERU Research Institute.

Zainuri, M., Matsum, JH, \& Thomas, Y. (2014). Income Level, Socio-Culture and Distance between Houses and Schools as Factors for Children to Drop Out of School at SMPN. Journal of Education and Learning, 3 (10), 1-15. 